Management international

International Management

Gestiòn Internacional

\title{
University Students and their faculty: Perceptions of entrepreneurial optimism, overconfidence and entrepreneurial Intentions
}

Les étudiants et leurs professeurs : optimisme, excès de confiance et intention entrepreneuriale

\section{Los estudiantes y sus profesores: optimismo, exceso de confianza e intencion empresarial}

Olivier Giacomin, Frank Janssen et Rachel S Shinnar

Volume 20, numéro 1, automne 2015

URI : https://id.erudit.org/iderudit/1045360ar

DOI : https://doi.org/10.7202/1045360ar

Aller au sommaire du numéro

Éditeur(s)

HEC Montréal

Université Paris Dauphine

ISSN

1206-1697 (imprimé)

1918-9222 (numérique)

Découvrir la revue

Citer cet article

Giacomin, O., Janssen, F. \& Shinnar, R. S. (2015). University Students and their faculty: Perceptions of entrepreneurial optimism, overconfidence and entrepreneurial Intentions. Management international / International Management / Gestiòn Internacional, 20(1), 123-134.

https://doi.org/10.7202/1045360ar
Résumé de l'article

Si une carrière entrepreneuriale requiert un certain niveau d'optimisme et de confiance, l'excès de ceux-ci peut nuire au succès entrepreneurial. En comparant leurs perceptions à celles de leurs professeurs, nous analysons dans quelle mesure les étudiants sont plus optimistes quant aux bénéfices attendus d'une carrière entrepreneuriale et trop confiants par rapport aux barrières à l'entrepreneuriat. Nos résultats montrent que les étudiants sont plus optimistes, mais pas plus confiants, que leurs professeurs. Finalement, les étudiants plus optimistes et plus confiants ont une disposition et une intention entrepreneuriales plus importante que les autres.
Tous droits réservés (C) Management international / International Management / Gestión Internacional, 2015
Ce document est protégé par la loi sur le droit d'auteur. L’utilisation des services d'Érudit (y compris la reproduction) est assujettie à sa politique d'utilisation que vous pouvez consulter en ligne.

https://apropos.erudit.org/fr/usagers/politique-dutilisation/ 


\title{
University Students and their faculty: perceptions of entrepreneurial optimism, overconfidence and entrepreneurial Intentions
}

\author{
Les étudiants et leurs professeurs : optimisme, \\ excès de confiance et intention entrepreneuriale
}

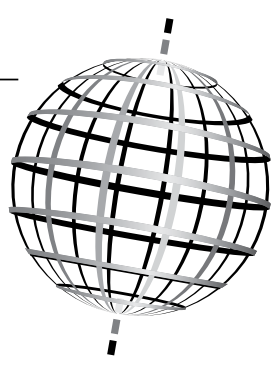

\section{Los estudiantes y sus profesores: optimismo, exceso de confianza e intencion empresarial}

\author{
OLIVIER GIACOMIN \\ European Business School Paris
}

\section{RÉSUMÉ}

Si une carrière entrepreneuriale requiert un certain niveau d'optimisme et de confiance, l'excès de ceux-ci peut nuire au succès entrepreneurial. En comparant leurs perceptions à celles de leurs professeurs, nous analysons dans quelle mesure les étudiants sont plus optimistes quant aux bénéfices attendus d'une carrière entrepreneuriale et trop confiants par rapport aux barrières à l'entrepreneuriat. Nos résultats montrent que les étudiants sont plus optimistes, mais pas plus confiants, que leurs professeurs. Finalement, les étudiants plus optimistes et plus confiants ont une disposition et une intention entrepreneuriales plus importante que les autres.

Mots clés : Intention entrepreneuriale, optimisme, excès de confiance

\author{
FRANK JANSSEN \\ Louvain School of Management \\ Université Catholique de Louvain
}

\section{ABSTRACT}

While an entrepreneurial career requires some level of optimism and confidence, unfounded optimism and overconfidence can be detrimental to entrepreneurial success. By comparing student and faculty perceptual differences, we assess whether university students are overly optimistic regarding the outcomes they expect from an entrepreneurial career as well as overconfident in their perceptions of barriers to entrepreneurship. Findings suggest that, overall, students are more optimistic but not more confident than faculty. Also, students who are more optimistic and more confident than their faculty, also perceive themselves to be more entrepreneurial and have stronger entrepreneurial intentions than their peers.

Keywords: Entrepreneurial intentions, optimism, overconfidence

\author{
RACHEL S SHINNAR \\ Walker College of Business \\ Appalachian State University
}

\section{RESUMEN}

Si una carrera empresarial exige un cierto nivel de optimismo y de confianza, un exceso de optimismo y de confianza puede ser perjudicial para el éxito empresarial. Comparando las percepciones a las de sus profesores, analizaremos en qué medida los estudiantes son más optimistas sobre los beneficios que esperan de una carrera empresarial y demasiado confiados con respecto a las barreras a la actividad empresarial. Nuestros resultados demuestran que los estudiantes son más optimistas, pero no tienen más confianza que sus profesores. Finalmente, los estudiantes más optimistas y con más confianza tienen una disposición empresarial más importantes que los otros.

Palabras Claves: Intención empresarial, optimismo, exceso de confianza
$\mathrm{O}$ verconfidence and unfounded optimism among university students have been documented across various disciplines (Bell \& Volckmann, 2011; Koku \& Qureshi, 2004; Haynes et al., 2006; Nowell \& Alston, 2007; Svanum \& Bigatti, 2006) but only to a limited extent in management education (Grimes, 2002; Grimes, Millea \& Woodruff, 2004; Nolan \& Provost, 2009), with a focus on entrepreneurship education still lacking. Overconfidence and unfounded optimism among entrepreneurship students merits further research attention given the important role that both play in the business startup decision making process (Griffin \& Tversky, 1992; Forbes, 2005; Hoffrage, 2004; Trevelyan, 2008; Weinstein, 1980). Optimism is regarded as a personality trait and is linked to positive outcomes in health, stress, and coping (Brissette et al., 2002). It can be an important determinant in the decision to give up or persist (Luthans, Avey \& Patera, 2008; Peterson,
2000). Optimism, however, may be problematic when positive expectations do not correspond with objective reality (Haynes et al., 2006). Overconfidence, which is a cognitive bias, is defined as an individual's tendency to overestimate ability and probability of gaining positive outcomes (Cheng, 2007). It describes decision makers' tendency to unwittingly give excessive weight to the assessment of knowledge and accuracy of information they possess as well as an unwarranted belief in the accuracy of their judgments (Lichtenstein \& Fischhoff, 1977). Cheng (2007) suggests that overconfident behavior is a common characteristic found in humans and often a result of individual tendency to seek confirmatory evidence while ignoring contradictory information.

In this paper, we assess students' overconfidence in underestimating the importance of barriers to entrepreneurship and optimism in overestimating the importance of 
positive outcomes that they expect to gain from an entrepreneurial career, as compared to faculty perceptions. We further examine the impact students' perceptions have on their entrepreneurial disposition and intentions. Doing so, will allow us to assess whether unfounded optimism and overconfidence are prevalent among entrepreneurship students and whether there is a need for entrepreneurship educators to harness students' optimism and confidence. This could possibly help educators lower the number of early start-up failures by cooling their students' ardors. The paper will be organized as follows: We begin with a review of the relevant literature on overconfidence and optimism, continue by describing the sample and methodology used, present and discuss our findings, list the study's limitations and conclude by presenting the implications for research and practice.

\section{Student Optimism and Overconfidence}

Saunders, Nolan and Provost (2009) studied optimism among Australian undergraduate business students, finding that students who fail might be overly optimistic about their ability to perform academically. Svanum and Bigatti (2006) also found considerable grade optimism among the majority (70\%) of their U.S. based university student sample. Similarly, Haynes et al. (2006) identified high levels of optimism among high school graduates regarding their potential to succeed in college which was "problematic in terms of academic-related cognitions and achievement" (p. 722) when these students actually completed their first year in college. Overconfidence has also been the focus of several investigations (Bell \& Volckmann, 2011; Koku \& Qureshi, 2004; Miller \& Geraci, 2011; Nowell \& Alston, 2007; Trevelyan, 2008) suggesting that people in general, and students in particular, tend to over-estimate their abilities. Indeed, Bergman, Westerman and Daly (2010) indicate that U.S. college students are likely to have an inflated sense of self. Similarly, Nowell and Alston (2007) find that among economics university students, those with lower GPAs and those enrolled in lower division classes tended to exhibit overconfidence compared to their peers. Others (Grimes, 2002; Grimes, Millea \& Woodruff, 2004) also identified such tendencies among students in principles of economics courses who exhibited a pervasive degree of overconfidence regarding the grades they expected to receive on exams. Over-confidence was also identified among chemistry students (Bell \& Volckmann, 2011). Koku and Qureshi (2004) found that "high performing students are... better calibrated and exhibit lower levels of overconfidence" (p. 223) compared to low-performing students.

In this paper, we wish to examine whether students' optimism regarding academic performance, as identified in past studies, also exists in their career related expectations. More specifically, we question whether students' general tendency to be overconfident and optimistic also shapes their perceptions of barriers to an entrepreneurial career and outcomes associated with such a career. We assess students' optimism and overconfidence by comparing their perceptions to those of their faculty. Given that, in the academic setting, faculty members are responsible for grading, we use faculty perceptions as the base point against which we compare student perceptions. In addition, given Sitzmann et al.'s (2010) findings showing a weak relationship between selfassessment of knowledge and actual knowledge, suggesting that "self-assessed knowledge is generally more useful as an indicator of how learners feel about a course than as andicator of how much they learned from it" (p. 180), we felt that faculty evaluation would be a more valid base of comparison rather than students' self-evaluations. Indeed, significant perceptual and attitudinal differences between students and faculty have been identified (Payne \& Holmer, 1998; Wood, 2006) and are discussed in the following section.

Generational differences between students and faculty have been identified in communication style, preference for using communication technology (Perlmutter, 2011), preference for technology use in the classroom (Wright \& Abell, 2011) and in students' preference for multitasking and active learning (such as learning in work groups and simulations vs. lectures) (Pardue \& Morgan, 2008). Some also examine this gap in relation to career performance. For example, Twenge (2009) points to the generational gap between today's students and their professors. His discussion focuses on medical education, where, he suggests "it is vital that faculty...temper overconfidence and excessive risk-taking” (p. 402). Twenge (2009) adds that for students born in the 1990s, also known as "Generation Me,...overconfidence ....may need to be tempered" (p. 398). While it is beyond the scope of our study, some research findings report that narcissism is increasing among university students, especially in the U.S. (Twenge et al., 2008). Narcissism, a sub-clinical personality trait, describes individuals who have an inflated sense of self, high self-esteem and a high sense of entitlement, beyond what would be considered a "realistic assessment and acceptance of one's strengths and weaknesses" (Bergman, Westerman \& Daly, 2010, p. 119). This personality trait may have implications for entrepreneurial behavior as Mathieu and St. Jean (2013) find a link between narcissism and entrepreneurial intentions and Campbell, Goodie and Foster (2004) find that narcissism is related to overconfidence and risk acceptance.

Given students' tendency to be overly optimistic and confident regarding their academic performance, we would expect these same attitudes to apply to career expectations as well. Namely, we believe that students may be overconfident in under-evaluating the importance of certain barriers to an entrepreneurial career, such as lack of competence or assistance. Students may also be overly optimistic in evaluating the importance of positive outcomes associated with this career, such as becoming financially independent by building personal wealth. Research evidence suggests that some of these outcome expectations may be unrealistic. In fact, "long hours, heavy [work] load and constant stress" (Roberts, 1997, p. 15), as well as challenges in balancing work and family (Shelton, Danes \& Eisenman, 2008) are common concerns for entrepreneurs. Furthermore, many entrepreneurs are burdened with the "financial risks associated with selfemployment... less job security... fewer fringe benefits... no health care insurance... and greater vulnerability of small business to market shifts and macroeconomic downturns" 
(Feldman \& Bolino, 2000, p. 63). Finally, reports from the Bureau of Labor statistics indicate that about $34 \%$ of small businesses in the U.S. are no longer in existence within the first two years and $56 \%$ within the first four years (Knaup, 2005). Indeed, Theng and Boon (1996) show that the main reasons for failing are endogenous to the firm and have to do with the entrepreneurs' lack of financial/managerial knowledge and skills. These findings speak to the importance of keeping students' expectations regarding career outcomes and possible barriers in check. Given research evidence on students' optimism and overconfidence, we propose that:

H1: Students will rank positive outcomes as more important and barriers as less important compared to faculty rankings.

\section{Optimism and Overconfidence among Entrepreneurs}

Optimism and overconfidence have been identified as common traits among entrepreneurs (Bernardo \& Welch, 2001; Griffin \& Tversky, 1992; Forbes, 2005; Hoffrage, 2004; Hmieleski \& Baron, 2008; Trevelyan, 2008; Weinstein, 1980). Optimism has been shown to promote persistence (Seligman \& Shulman, 1986), creativity (Li \& Wu, 2011), commitment (McColl-Kennedy \& Anderson, 2005), and an ability to influence others to commit to the venture (Ottsen \& Gronhaug, 2005). Trevelyan (2008) argues that both optimism and overconfidence are beneficial when deciding to become an entrepreneur because entrepreneurs "downplay uncertainty or setbacks and focus on what is good in a situation" (p. 988), further pointing out that optimistic entrepreneurs are more likely to pursue entrepreneurial activities and persist in the face of obstacles. Others (Camerer \& Lovallo, 1999; Simon \& Houghton, 2003) also consider overconfidence and its impact on business and new product entry decisions respectively, identifying a positive correlation between overconfidence and a willingness to pioneer. Busenitz and Barney (1997) also find that overconfidence in personal ability and unfounded optimism for favored outcomes play a role in entrepreneurial entry.

While entrepreneurial activity requires a certain degree of confidence and motivation, it can be less effective when confidence is too high. High entrepreneurial confidence can therefore help but also harm efforts to establish and grow a venture because "under conditions of uncertainty, excess confidence in one's knowledge and abilities leads to complacency" (Trevelyan, 2011, p. 4). Several studies warn against the risks of overconfidence among decision makers associating it with poor decisions (Hayward \& Hambrick, 1997) and rigidity (Audia et al., 2000). Palich and Bagby (1995) find that entrepreneurs have a tendency to magnify the strengths and opportunities and downplay the importance of threats and barriers to venture creation. Similarly, Griffin and Tversky (1992) suggest that entrepreneurs might be subject to overconfidence in declarative knowledge (say in relation to the attractiveness of their offering, customer demand or competitor agility), judgment of their own managerial abilities, prediction of positive outcomes and ability to control events. This also includes an overconfidence bias in the area of financial decision-making as identified by Cooper et al. (1988). The risk of overconfidence among entrepreneurs was also identified by Koellinger, Minniti and Schade (2007) who, in their GEM-data based study covering 18 nations, found "a significant and negative relation between entrepreneurial self-confidence and survival rates of nascent entrepreneurs across countries. This result provides some evidence that the perception of entrepreneurial skills is likely to be biased by overconfidence" (p. 520). Hayward, Shepherd and Griffin (2006) warn that excess confidence in themselves and the business opportunity can lead entrepreneurs to overestimate the likelihood that their ventures will succeed. They add that excessively confident entrepreneurs may put less effort into attaining and mobilizing resources, in the belief that the venture does not need high levels of, for example, investment, cash, social networks, or legal protection. Trevelyan (2008) also found that overconfidence is harmful when making decisions in response to setbacks. Similarly, Lowe and Ziedonis (2006) found that overconfident entrepreneurs continue unsuccessful development efforts for longer periods of time. In the same vein, Hmieleski and Baron (2009) found that overconfidence among founding managers can have a negative effect on the financial performance of their firms, especially if those firms operate in a dynamic environment.

Given the possible drawbacks of overconfidence and excess optimism, we believe it is imperative to assess whether these attitudes and/or dispositions affect how students and aspiring entrepreneurs view themselves. We expect that, in comparison to faculty rankings, students who (a) rank the positive outcomes associated with entrepreneurship as more important and (b) rank barriers to entrepreneurship as less important, will also have a stronger entrepreneurial disposition. We thus propose that:

$\mathrm{H} 2$ : Students who rank positive outcomes as more important and barriers as less important compared to faculty rankings will perceive themselves as more entrepreneurial compared to their peers.

Overconfidence and unfounded optimism may also direct individual behaviors and therefore, have a strong impact on entrepreneurial intentions as well. We examine this relationship next.

\section{Entrepreneurial Intentions}

Social cognitive theory (Bandura, 1997) proposes that, before an individual initiates and pursues goal-directed tasks, he/ she invokes personal cognitive capabilities to weigh, evaluate, and integrate information about personal skills relative to specific challenges and to form beliefs about probabilities of attaining success. The strength of these beliefs and certainty with which they are held are personal self-efficacy beliefs relative to that set of challenges (Bandura, 1997; Stajkovic \& Luthans, 1998). In the same vein, Koellinger et al. (2007) add that "for decisions made under uncertainty, such as starting a new business, perceptions are a mediator between preferences and behavior, affecting perceptions of both probabilities and outcomes" (p. 505). An assessment 
of one's confidence is situation specific and applied to particular tasks (Gist \& Mitchell, 1992). Indeed, entrepreneurial confidence has been linked to persistence (Seligman \& Schulamn, 1986) as well as motivation (Bandura, 1997) and innovation (Simon \& Houghton, 2003). When entrepreneurs are optimistic and overconfident they have a "rose tinted view of the world [which] not only encourages...[them] to enter into markets that have yet to be proven but ...also allows them to continue with courses of action when faced with setbacks" (Trevelyan, 2008, p. 988). Optimism creates positive expectations that can act to motivate action (Scheier, Carver \& Bridges, 2001). Behavioral intentions can be therefore shaped by one's overconfidence in estimating abilities to make accurate forecasts about the likelihood of success. Excessive optimism about the outcomes associated with an entrepreneurial career may also act to shape individual behavioral intentions. We would therefore expect that students who, in comparison to their faculty, are optimistic and overconfident, will have stronger behavioral intentions and propose that:

H3: Students who perceive barriers as less important and positive outcomes as more important compared to faculty perceptions will have stronger entrepreneurial intentions.

\section{Methodology}

\section{SURVEY INSTRUMENT}

Our sample includes 1974 students (311 American, 390 Belgian, 320 Chinese, 366 Indian and 587 Spanish) and 405 faculty (84 American, 10 Belgian, 23 Chinese, 72 Indian and 216 Spanish) from a single university in each nation (U.S., Belgium, China, India and Spain). Data collection took place at the different universities over the course of a three year period between 2006 and 2008. Respondents included students and faculty from various fields of study including: art, communication, political sciences, law, sociology, foreign languages, history, management, engineering, and computer information systems. The rationale for covering a broad student body, versus narrowly focusing on business majors only, is based on the growing trend of expanding entrepreneurship education beyond the walls of business schools (Maguire \& Guyer, 2004; Mangan, 2004). Student samples are very common in entrepreneurship research (Liñan \& Chen, 2009) especially given evidence that university graduates between 25 and 34 years of age show the highest propensity toward starting up a firm (Reynolds et al., 2004).

Our survey instrument is based on a study carried out by Genescá and Veciana (1984) and replicated several times in Spain (Veciana et al., 2005). Their survey was designed based on Shapero's (1982) model which proposes that the intent to start a business is derived from perceptions of both desirability and feasibility. Therefore, survey items assessed the degree to which respondents perceived entrepreneurship to be desirable (by assessing importance given to various outcomes) and feasible (by assessing importance given to various barriers). We used the original questionnaire developed by Veciana et al. (2005) with additional demographic questions. The original questionnaire was administered in Spanish to the students in Spain. It was translated into English $^{1}$ (for the American, Chinese and Indian students) and into French (for the Belgian students). The questionnaires were back-translated into the language of origin to assure no loss of meaning. Questionnaires were administrated during class sessions, yielding a response rate of close to $100 \%$. Using Likert scales and demographic variables, we measured students' perceptions of the importance of barriers to business startup, importance of positive outcomes associated with an entrepreneurial career, their entrepreneurial disposition, as well as their entrepreneurial intentions.

\section{VARIABLES}

To assess students' overconfidence, we measured the importance they gave to different barriers to entrepreneurship and compared student ratings to faculty ratings of the same barriers. To assess students' optimism we measured the importance students gave to various positive outcomes associated with an entrepreneurial career and compared student ratings to faculty ratings of the same motivations. Both barriers and outcome expectations were measured on a five-point Likert asking students: "How would you rate the importance of the following barriers (motivators) to starting a business?" Responses ranged from " 1 " being "very unimportant" to "5" being "very important." The barriers included: (1) Lack of entrepreneurial competence, (2) Lack of knowledge, (3) Lack experience in management and accounting, (4) Lack of assistance in assessing viability, (5) Lack of knowledge of business world and market, (6) Lack of assistance to entrepreneurs, (7) Lack of formal help to start a business, and (8) Lack of legal assistance of counseling. The positive outcomes included: (1) Receive fair compensation, (2) Financial independence, (3) Heading an organization, (4) Build personal wealth, (5) Managing people, and (6) Gain high social status.

Entrepreneurial disposition was measured on a sevenpoint Likert scale asking the students to rank themselves in relation to the following statement: "Please indicate the degree to which you consider yourself an entrepreneur, full of ideas and initiative to start your own business." Possible responses ranged from "1" being "not entrepreneurial at all" to " 7 " being "very entrepreneurial." Entrepreneurial intentions were measured by a single item, an approach used in several recent publications (Díaz \& Jiménez, 2010; Fitzsimmons \& Douglas, 2005; Graevenitza, Harhoffa \& Weberb, 2010; Veciana et al., 2005). Students were asked to answer the following question: "Have you ever thought of starting a business?" Responses were measured on a fourpoint Likert scale ranging from " 0 " being "No, never," to " 3 " being "Yes, I have a definite plan to start my own business."

1. For the Chinese students, who were taking English language classes and thus proficient in English, verbal clarifications were given when necessary during survey administration. 
Level of exposure to entrepreneurship education was assessed by asking students: "How much knowledge does your curriculum provide you in terms of starting your own business?" Responses were measured on a four-point Likert scale ranging from " 1 " being "None" to "4" being "A lot." For the purposes of our analysis, the four categories were collapsed into a dichotomous variable. Those who selected "None" or "Little" were coded as "zero" and labeled as having little to no exposure to entrepreneurship education (NEE). Those who selected "Some" or "A lot" were coded as "one" and labeled as having moderate to high exposure to entrepreneurship education (HEE) ${ }^{2}$.

\section{Data Analysis}

We followed a three stage procedure for our data analysis. First, we examined the expected outcomes and the perceived barriers for all students and faculty. To accomplish this, we applied a principal component factor analysis to expected outcome and barrier items. This allowed us to identify different groups of expected outcomes and perceived barriers for both the student and the faculty samples. In the second stage, we created four new variables: two related to student expected outcomes and two related to student expected barriers. To create these new student variables, we calculated the mean value of the set of variables in each PCA factor. Next, we compared the students' value variables to the faculty value variables to differentiate between two student groups: (1) students ranking positive outcomes as more important and barriers as less important compared to faculty and (2) students ranking positive outcomes as less important and barriers as more important compared to faculty. We used the faculty mean value as the discriminate value. In the last step, in order to confirm our set of hypothesis, we applied a set of t-tests.

\section{Results}

The PCA results for the motivation items (See Table 1), show that two factors with an eigenvalue greater than one emerged in each sample (student and faculty). These were labelled as Perceived Financial outcome and Perceived Social Status outcome. Both KMO and Bartlett's tests suggest that our data are suitable for factor analysis. The cumulative variance explained by these two factors is $59.22 \%$ for the student subsample, and $61.21 \%$ for the faculty sub-sample. Table 1 presents the rotated factor matrix.

The PCA results for the barrier items (See Table 2), show that two factors with an eigenvalue greater than one emerged in each sample (student and faculty). We labelled these factors as Perceived Lack of Competency and Perceived Lack of Support. Both KMO and Bartlett's tests suggest that our data are suitable for factor analysis. The cumulative variance explained by these two factors is $54.41 \%$ for the Student subsample, and $57.74 \%$ for the faculty sub-sample. Table 2 presents the rotated factor matrix.

As indicated in Table 3, students are, on average, significantly more optimistic than their professors in terms of the financial (student mean $=3.71$; faculty mean $=3.40$ ) and social (student mean $=3.47$; faculty mean $=3.17$ ) outcomes expected to be gained through an entrepreneurial career. Conversely, if we compare the perceptions in terms of the expected barriers both in terms of competency and support, we see that, on average, students are less confident than their faculty (albeit not significantly so), ranking the barriers as more important than faculty did (student mean competency $=3.61$; faculty mean competency $=3.54$ and student mean support $=3.38$; faculty mean support $=3.29$ ) .

These results offer partial support for our first hypothesis (H1), showing that students are more optimistic than their faculty in their ranking positive outcomes as significantly more important compared to faculty rankings thereof. No statistically significant difference was found, however, between students and faculty in rating the importance of barriers, indicating that, overall, students do not have a tendency to be overconfident in comparison to their professors.

Once the student respondents were separated into two groups, those ranking higher on perceived importance of

\begin{tabular}{|c|c|c|c|c|}
\hline \multirow[b]{3}{*}{ FACTOR ANALYSIS INDICATORS } & \multirow{2}{*}{\multicolumn{2}{|c|}{$\begin{array}{c}\text { TABLE } 1 \\
\text { comes, Exploratc } \\
\text { Student sub-sample }\end{array}$}} & nalysis (V & \\
\hline & & & \multicolumn{2}{|c|}{ Faculty sub-sample } \\
\hline & FINANCE & STATUS & FINANCE & STATUS \\
\hline Receive fair compensation & .817 & -.104 & .654 & -.038 \\
\hline Financial independence & .649 & .270 & .729 & .164 \\
\hline Heading an organization & .152 & .856 & .244 & .828 \\
\hline Build personal wealth & .609 & .374 & .770 & .165 \\
\hline Managing people & .184 & .820 & .046 & .876 \\
\hline Gain high social status & .307 & .559 & .272 & .691 \\
\hline
\end{tabular}

Finance: perceived financial expected outcome; Status: perceived social status outcome.

For Students: KMO $=0.748$ \& Bartlett's test $p<0.001$; For Faculty: KMO $=0.702$ \& Bartlett's test $p<0.001$; PCA performed with SPSS 19.0

* The boldface values represent the most significant indicators for the factors Finance and Status for each sub-sample. 


\title{
TABLE 2
}

Entrepreneurship Expected Barriers, Exploratory Factor Analysis (Varimax)*

\begin{tabular}{|c|c|c|c|c|}
\hline & \multicolumn{2}{|c|}{ Student sub-sample } & \multicolumn{2}{|c|}{ Faculty sub-sample } \\
\hline FACTOR ANALYSIS INDICATORS & COMPETENCY & SUPPORT & COMPETENCY & SUPPORT \\
\hline Lack of entrepreneurial competence & .596 & .098 & .547 & .172 \\
\hline Lack of knowledge & .797 & .115 & .812 & .131 \\
\hline Lack experience in management \& accounting & .773 & .153 & .813 & .120 \\
\hline Lack of assistance in assessing viability & .420 & .569 & .310 & .653 \\
\hline Lack of knowledge of business world \& market & .614 & .357 & .440 & .115 \\
\hline Lack of assistance to entrepreneurs & .143 & .699 & .143 & .844 \\
\hline Lack of formal help to start a business & .124 & .819 & .109 & .849 \\
\hline Lack of legal assistance of counseling & .173 & .768 & .175 & .844 \\
\hline
\end{tabular}

Competency: Perceived lack of competency; Support: Perceived lack of support.

For Students: $\mathrm{KMO}=0.823$ \& Bartlett's test $p<0.001$; For Faculty: KMO $=0.794$ \& Bartlett's test $p<0.001$; PCA performed with SPSS 19.0

* The boldface values represent the most significant indicators for the factors Finance and Status for each sub-sample.

\section{TABLE 3}

\section{Entrepreneurship Outcomes and Barriers: Student and Faculty Comparisons, $t$-test}

\author{
Expected outcomes (mean value) Expected barriers (mean value)
}

\begin{tabular}{|l|l|l|l|l|l|}
\hline FACTOR ANALYSIS INDICATORS & COMPETENCY & SUPPORT & \multicolumn{2}{c|}{ COMPETENCY } & SUPPORT \\
\hline Student & 3.71 & 3.47 & 3.61 & 3.38 \\
\hline Faculty & 3.40 & 3.17 & 3.54 & 3.29 \\
\hline Mean difference & $.31^{* *}$ & $.30^{* *}$ & .07 & .09 \\
\hline
\end{tabular}

$* * p<0.01$

motivators than their faculty (overly optimistic) and those ranking the same or lower on perceived importance of barriers (overconfident), we found support for our remaining hypothesis (See Table 4). Based on these results, the second hypothesis (H2) was supported, showing that the overly optimistic and overconfident students also perceived themselves as more entrepreneurial compared to their peers. As proposed in our third hypothesis (H3), these same students also had stronger entrepreneurial intentions compared to their peers who ranked positive outcomes as less important and barriers as more important compared to faculty rankings.

\section{Post-Hoc Analysis}

We conducted a post-hoc analysis, in order to examine whether exposure to entrepreneurship education would have an impact on our findings. Our sample was divided into two categories according to level of exposure to entrepreneurship education among the student respondents: (a) students with some or much exposure (HEE) and (b) students with little to no exposure (NEE). Results are presented below in Table 5.

As indicated in Table 5, students who had moderate to high exposure to entrepreneurship education (HEE) are, on average, significantly more optimistic than their professors in terms of both the financial (student mean $=3.75$; faculty mean $=3.33$ ) and social (student mean $=3.49$; faculty mean
$=3.11$ ) outcomes expected to be gained through an entrepreneurial career. The same is true for the students who had little or no exposure to entrepreneurship education (NEE) who are also, on average, significantly more optimistic than their professors in terms of the financial (student mean $=3.66$; faculty mean $=3.40$ ) and social (student mean $=3.45$; faculty mean $=3.17)$ outcomes expected to be gained through an entrepreneurial career.

If exposure to entrepreneurship education does not make a difference in terms of optimism, the same does not hold for overconfidence: When perceptions in terms of the expected barriers (competency and support) were compared, HEE students are, on average, less overconfident than their professors, ranking the barriers as significantly more important than faculty did (on both competency: student mean $=3.68$; faculty mean $=3.54$ and support: student mean $=3.43$; faculty mean $=3.30$ ). In contrast, the way their NEE counterparts perceived barriers (competency or support), did not differ significantly from faculty perceptions thereof (see Table 5). Thus, students who have had some or a lot of exposure to entrepreneurship education do not seem to be overconfident.

To examine the impact of exposure to entrepreneurship education on students' perceptions and intentions, the HEE and NEE student groups were further separated: those who ranked positive outcomes as more important and barriers as 
TABLE 4

Entrepreneurial Intention and Disposition: Student Comparisons, $t$-test

\begin{tabular}{|l|l|l|}
\hline STUDENT'S SUB-SAMPLE & ENTREPRENEURIAL INTENTION & ENTREPRENEURIAL DISPOSITION \\
\hline Student overconfident and overly optimistic (S1) & 1.41 & 4.60 \\
\hline Student less confident and/or less optimistic (S2) & 1.20 & 4,20 \\
\hline Mean difference & $.21^{* *}$ & $.40^{* *}$ \\
\hline
\end{tabular}

${ }^{* *} \mathrm{p}<0.01 ; \mathrm{S} 1: \mathrm{n}=224$ students and $\mathrm{S} 2: \mathrm{n}=1750$ students

\section{TABLE 5}

\section{Perceived Outcomes and Barriers: HEE \& NEE Students to Faculty Comparisons, $t$-test}

\begin{tabular}{|l|l|l|l|l|}
\hline & \multicolumn{2}{l}{ Expected outcomes (mean value) } & \multicolumn{3}{c|}{ Expected barriers (mean value) } \\
\hline SUB-SAMPLE & FINANCE & \multicolumn{1}{c}{ STATUS } & \multicolumn{2}{c|}{ COMPETENCY } \\
\hline Faculty & 3.40 & 3.17 & 3.54 & 3.30 \\
\hline HEE Students & 3.75 & 3.49 & 3.68 & 3.43 \\
\hline Mean difference HEE students/faculty & $.35^{* *}$ & $.32^{* *}$ & $.14^{* *}$ & $.13^{*}$ \\
\hline NEE Students & 3.66 & 3.45 & 3.54 & 3.33 \\
\hline Mean difference NEE students/faculty & $.26^{* *}$ & $.28^{* *}$ & .00 & .03 \\
\hline
\end{tabular}

HEE ( $n=1012)$ : Students with some/much exposure to entrepreneurship education; NEE (n=962): Students with very little/no exposure to entrepreneurship education; ${ }^{*} \mathrm{p}<0.05 ;{ }^{* *} \mathrm{p}<0.01$

less important compared to faculty rankings thereof (namely those who are considered overconfident and optimistic). This resulted in a total of four groups. Results, presented in tables $6 \mathrm{a}$ and $6 \mathrm{~b}$, show that among HEE and NEE students, those who are overly optimistic and overconfident, also perceived themselves as more entrepreneurial compared to their peers and had stronger entrepreneurial intentions as well. These findings are consistent for the sample as a whole regardless of the students' level of exposure to entrepreneurship education.

\section{Discussion}

Our results show that, overall, students are not overconfident in terms of ranking barriers to entrepreneurship too lightly. They do, however, appear to be overly optimistic regarding the outcomes associated with an entrepreneurial career. These results indicate that students were overly optimistic in rating the positive aspects of being an entrepreneur such as earning high income, having high social status, or leading an organization. We also show that this is the case independently of whether they have been exposed to entrepreneurship education or not: All students were overly optimistic regarding the financial and status outcomes regardless of their level of exposure to entrepreneurship education. This probably has to do with the fact that in many societies, entrepreneurs are seen as modern economy's most important actors (Lazear, 2005). This status of "heroic symbol" comes from an economic and political, but also cultural and moral, construction in which qualities such as effectiveness, innovation or creativity are opposed to bureaucracy's ineffectiveness, routine or disillusion (Jones \& Spicer, 2009). From that perspective, entrepreneurship is mainly associated with positive aspects such as growth, innovation and wealth creation, which may act to shape students' perceptions.

The finding regarding students' optimism suggests that faculty in general, and entrepreneurship faculty in particular, would need to sensitize their students to the reality of being an entrepreneur, which can present significant challenges such as long hours, heavy work load, stress (Roberts, 1997), financial risks, less job security, fewer benefits (e.g., no paid vacation, no health insurance), greater vulnerability to market shifts and macroeconomic downturns (Feldman \& Bolino, 2000), challenges in balancing work and family (Shelton, Danes \& Eisenman, 2008) and of course, high failure rates (Knaup, 2005). The fact that, on average, all students-regardless of level of exposure to entrepreneurship education-were likely to be optimistic about financial and status outcomes expected from an entrepreneurial career, further underlines the important role of entrepreneurship faculty in tempering students' unfounded optimism and shaping more realistic expectations. Professor David Storey at Sussex University stresses that unfounded optimism may be detrimental to entrepreneurs who make decisions with imperfect information. He uses the economic theory of the gambler's ruin to suggest that running a business involves risk, much like sitting at a roulette table. Storey uses this analogy to explain why some entrepreneurs end up in trouble given that as "the theory of the gambler's ruin... explain[s,] 'the house always wins' because a casino, with more resources at its disposal, can always afford to play for longer than any individual gambler" (Moules, 2012, p.195). 


\begin{tabular}{|c|c|c|}
\hline \multicolumn{3}{|c|}{$\begin{array}{l}\text { TABLE 6A } \\
\text { Entrepreneurial Intention and Disposition: HEE Student Comparisons, } t \text {-test }\end{array}$} \\
\hline & ENTREPRENEURIAL INTENTION & ENTREPRENEURIAL DISPOSITION \\
\hline HEE Students overconfident and overly optimistic (S1) & 1.51 & 4.92 \\
\hline HEE Students less confident and/or less optimistic (S2) & 1.26 & 4,43 \\
\hline Mean difference & $.25^{* *}$ & $.49 * *$ \\
\hline
\end{tabular}

${ }^{* *} p<0.01$

\begin{tabular}{|c|c|c|}
\hline \multicolumn{3}{|c|}{$\begin{array}{l}\text { TABLE 6B } \\
\text { Entrepreneurial Intention and Disposition: NEE Student Comparisons, } t \text {-test }\end{array}$} \\
\hline & ENTREPRENEURIAL INTENTION & ENTREPRENEURIAL DISPOSITION \\
\hline NEE Students overconfident and overly optimistic (S1) & 1.34 & 4.39 \\
\hline NEE Students less confident and/or less optimistic (S2) & 1.13 & 3,95 \\
\hline Mean difference & $.21^{* *}$ & $.44^{* *}$ \\
\hline
\end{tabular}

${ }^{* *} p<0.01$

Educators can play a significant role in shaping their students' expectations. For example, Mayo et al. (2012) found that receiving feedback from peers lowered individuals' evaluation of their own competencies thus aligning self-evaluations of competencies with others' evaluation thereof. Others (Bandura, 1997; Russo \& Schoemaker, 1992) also suggest that students' attitudes can be manipulated through awareness and training. Faculty attitudes can be instrumental in shaping student attitudes as demonstrated by Egan (1973) who argues that students' attitudes are "by and large, congruent with the attitudes of their teachers" (p. 316) in, for example, liking or disliking a subject matter. Similarly, Haynes et al. (2006) showed that an intervention with high school graduates who were overly optimistic regarding their expected success in college, resulted in higher academic performance, further speaking to the impact such interventions can have.

Our analysis further separated the students who were more confident and optimistic than their faculty from their peers who were less so. Those students who were more confident and optimistic, also perceived themselves as more entrepreneurial compared to their peers and had stronger entrepreneurial intentions. These results seem to indicate that students who are more confident and optimistic also view themselves as entrepreneurs and have stronger behavioral intentions to pursue an entrepreneurial career. Research evidence suggests that faculty can be instrumental in shaping students' social identities, such as perceiving themselves as entrepreneurial (Smith \& Woodworth, 2012). This stresses the importance and potential for faculty to proactively seek to temper students' expectations regarding an entrepreneurial career, especially among those students who are likely to be overconfident in the weight they give to barriers and overly optimistic regarding the outcomes associated with an entrepreneurial career. With about a third of small businesses failing within the first two years, and over half failing before the four year mark (Knaup, 2005), it appears to be necessary to help aspiring entrepreneurs align their expectations to the actual challenges and benefits awaiting a business owner. This undoubtedly represents a challenge, given that faculty would want to temper student attitudes without quenching their entrepreneurial aspirations all together. Students' excessive optimism could possibly be reduced through interactions with working entrepreneurs who share from their experience, not just the advantages and benefits of an entrepreneurial career, but also the challenges and hardships it encompasses.

However, the opposite perspective must also be considered here: the idea that failure can in fact act as a learning opportunity for entrepreneurs and contribute to their future success. As Moules (2012) suggests "it could be said that entrepreneurs who have not failed are either unsuccessful, liars or not experienced enough" (p. 197). This perspective would advocate that overly optimistic students must be allowed to fail, because this is part of the learning process in their journey to become successful entrepreneurs. Indeed, David Storey argues that "the optimistic belief that they are different from everyone else" (Moules, 2012, p. 197) is an essential characteristic among entrepreneurs. While Storey uses the theory of gambler's ruin to explain entrepreneurial failure he also argues that, in order to have an opportunity at winning, the entrepreneur must take a chance, or to use his lottery analogy: 'buy a lottery ticket.'

\section{Conclusion}

To summarize our main findings: Students are, on average, significantly more optimistic than their professors in terms of the importance they give to both financial and social outcomes expected to be gained through an entrepreneurial career. This is true regardless of students' level of exposure to 
entrepreneurship education. When perceptions of expected barriers (in terms of competency and support) were compared, students were not found to be overconfident in rating barriers to entrepreneurship too lightly. However, when exposure to entrepreneurship education was factored in, students with moderate to high exposure (HEE) perceived barriers as significantly more important than their faculty did, while those with little to no exposure (NEE) did not perceive barriers to be significantly different from faculty perceptions thereof. This appears to indicate that students who were exposed to entrepreneurship education do not have a tendency to be overconfident, a finding which is encouraging.

When the sample was separated into two groups -the overconfident and overly optimistic students (those students who ranked positive outcomes as more important and barriers as less important compared to faculty rankings thereof) findings indicate that the overly optimistic and overconfident students also perceived themselves as more entrepreneurial and had stronger entrepreneurial intentions compared to their peers who ranked positive outcomes as less important and barriers as more important compared to faculty rankings. These results remain consistent even once exposure to entrepreneurship education is taken into account. Namely, the students who are overly optimistic and overconfident are more likely to perceive themselves as entrepreneurial and have stronger entrepreneurial intentions, regardless of their degree of exposure to entrepreneurship education.

\section{Limitations}

This study suffers from a few limitations. First, we use faculty perceptions of the importance students give to possible barriers and positive career outcomes as the base of comparison. Faculty may have an overly conservative or pessimistic view of the importance students would give to certain barriers and/or to certain career outcomes. It would have possibly been more accurate to compare student perceptions to those of actual entrepreneurs. Furthermore, our sample consists of faculty from disciplines other than business (with the exception of the Belgian faculty sample) who may not have a good grasp of the opportunities and barriers entrepreneurship involves.

Second, gender was not included as a control variable in our study as this information was not available for the entire sample. This could have introduced some bias into our findings given research evidence that men tend to have stronger entrepreneurial intentions when compared to women (Chen et al., 1998; Zhao et al., 2005) and that women tend to be more risk averse in comparison to men (Carter, 2002; Eckel \& Grossman, 2003; Wagner, 2007). In addition, our data were collected through a survey instrument reported by the same group of respondents. Therefore, any observed relations may be in part a result of common method effect (Fiske, 1982). However, this limitation is consistent with the limitations of prior empirical studies in this area, and of most survey research. A final limitation is that the sample came from a single university in each country, limiting generalizability. Faculty and education programs at other schools will need to reach their own conclusions about the applicability of our results to their specific institutions.

\section{Implications for Practice and Areas for Future Research}

The challenge for faculty to walk the fine line between encouraging students and tempering unfounded optimism may be brought into the classroom. For example, faculty could lead a discussion in entrepreneurship courses regarding students' perceptions of and feelings about overconfidence and unfounded optimism. In addition, it may be important for faculty to center entrepreneurship education on the process of becoming an entrepreneur and starting a business versus the outcomes associated with an entrepreneurial career. Furthermore, students pursuing degrees outside the business school who have an interest in entrepreneurship should be advised to take part in such courses which may serve to shape their perceptions and help them form more realistic expectations.

Our sample includes faculty from several disciplines other than business (with the exception of the Belgian sample). It would be important to assess whether business faculty are better informed of the opportunities and challenges, and are thus less pessimistic compared to their peers in other disciplines, regarding the barriers students are likely to encounter and the outcomes students can realistically expect from an entrepreneurial career. In addition, future research could assess student optimism and overconfidence in relation to more objective measures such as actual performance in an entrepreneurship course. This could also be instructive in identifying whether actual performance in an entrepreneurship course (in terms of final course grade or grade on a business plan assignment for example) is related to the degree of optimism and overconfidence. A final most valuable research avenue would include a longitudinal examination, comparing aspiring entrepreneurs who went through an intervention aimed at tempering overconfidence and excess optimism to those who did not, and examining the impact this has on their actual success as business owners and their businesses' longevity later on.

Finally, given that our sample did not consist of business students or those students taking entrepreneurship courses, we cannot say with certainty that the perceptions of the students in our sample are a result of overconfidence and optimism or simply a sign of lack of experience and lack of relevant knowledge. Indeed, Simon et al. (2000) find that "individuals start ventures because they do not perceive the risks involved, and not because they knowingly accept high levels of risks" (p. 113). Thus, students may consider a certain barrier to be unimportant simply because they "might not acknowledge that certain tasks, important to the venture's success, are beyond their control" (Simon et al., 2000, p. 113). 


\section{References}

Audia, Pino G.; Locke, Edwin A.; Smith, Ken. (2000). “The paradox of success: An Archival and a Laboratory Study of Strategic Persistence Following Radical Environmental Change", Academy of Management Journal, vol. 43, $\mathrm{n}^{\circ}$ 5, p. 837-53.

Bandura, A. (1997). Self-efficacy: The exercise of control, New York: Freeman, $604 \mathrm{p}$.

Bell, Priscilla; Volckmann, David (2011). "Knowledge surveys in general Chemistry: Confidence, overconfidence and performance", Journal of Chemical Education, vol. 88, $\mathrm{n}^{\circ} 11$, p. $1469-1476$.

Bergman, Jacqueline Z.; Westerman, James W.; Daly, Joseph P. (2010). "Narcissism in management education", Academy of Management Learning \& Education, vol. 9, n 1, p. 119-131.

Bernado, Antonio E.; Welch, Ivo (2001). "On the evolution and overconfidence of entrepreneurs", Journal of Economics and Management Strategy, vol. 10, n⿳⺈ 3, p. 301-30.

Brissette, Ian; Scheir, Michael F.; Carver, Charles S. (2002). "The role of optimism in social network development, coping, and psychological adjustment during life transition", Journal of Personality and Social Psychology, vol. 82, $\mathrm{n}^{\circ}$ 1, p. 102-111.

Busenitz, Lowell W.; BARney, Jay B. (1997). “Difference between entrepreneurs and managers in large organizations: Biases and heuristics in strategic decision-making”, Journal of Business Venturing, vol. 12, $\mathrm{n}^{\circ}$ 1, p. 9-30.

Camerer, Colin; Lovallo, Dan (1999). "Overconfidence and excess entry: An experimental approach", American Economic Review, vol. 89, n 1, p. 306-18.

Campbell, Keith W.; Goodie, Adam S.; Foster, Joshua D. (2004). "Narcissism, confidence and risk attitude", Journal of Behavioral Decision Making, vol. 17, $\mathrm{n}^{\circ}$ 4, p. 297-311

CARTER, Nancy (2002). "The role of risk orientation on financing expectations in new venture creation: Does Sex Matter?", Babson College, Wellesley, MA: Frontiers of Entrepreneurial Research. Available at http: //www.babson.edu/entrep/fer/ Babson2002/VI/VI_P2/VI_P2.htm, accessed January 21, 2015.

Chen, Chao C.; Greene, Patricia Gene; Crick, Ann (1998). "Does entrepreneurial self-efficacy distinguish entrepreneurs from managers?", Journal of Business Venturing, vol. 13, $n^{\circ} 4$, p. 295-316.

Cheng, Philip Y. K., (2007). “The trader interaction effect on the impact of overconfidence on trading performance: An empirical study", Journal of Behavioral Finance, vol. 8, n 2, p. 59-69.

Cooper, Arnold; Woo, Carolyn Y.; Dunkelberg, William C. (1988). "Entrepreneurs perceived chances for success", Journal of Business Venturing, vol. 3, n², p. 97-108.

Eckel, Catherine C.; Grossman, Philip J. (2003). "Forecasting risk attitudes: An experimental study of actual and forecast risk attitudes of women and men". Accessed January 21, 2015 http: //web.stcloudstate.edu/pjgrossman/Forecasting\%20 Attitudes.pdf

Egan, A.L (1973). "Incidental learning: A study of attitudes", Education, vol. 93, $\mathrm{n}^{\circ}$ 4, p. 314-321.

Feldman, Daniel C.; Bolino, Mark C. (2000). "Career patterns of the self-employed: Career motivations and career outcomes", Journal of Small Business Management, vol. 38, n 3, p. 53-67.
Ferraro, Paul J. (2010). "Know thyself: Competence and selfawareness", Atlantic Economic Journal, vol. 38, n² 2, p. 183-196.

FISKE, Donald (1982). "Convergent-discriminant validation in measurement and research strategy", in D. Brinsberg, L. Kidder (Eds.), New Directions for Methodology of Social and Behavioral Sciences: Forms of Validity in Research, San Francisco, CA: Jossey Bass, p. 77-92.

Forbes, Daniel P. (2005). "Are some entrepreneurs more overconfident than others?", Journal of Business Venturing, vol. $20, \mathrm{n}^{\circ} 5$, p. 623-40.

Fitzsimmons, Jason R.; Douglas, EvanJ.(2005). “Entrepreneurial attitudes and entrepreneurial intentions: A cross-cultural study of potential entrepreneurs in India, China, Thailand and Australia", Babson-Kauffman Entrepreneurial Research Conference, Wellesley, MA. Available At http: //eprints.qut. edu.au/6486/1/6486.pdf, accessed January 21, 2015

Genesca, Enrique.; Veciana, José M. (1984). “Actitudes hacia la creación de empresas", Información Comercial Española, vol. 611, July, p. 147-155.

Gist, Marylin E.; Mitchell, Terence R. (1992). "Self-efficacy: A theoretical analysis of its determinants and malleability", Academy of Management Review, vol. 17, n² 2, p. 183-211.

Graevenitza, Georg; Harhoffa, Dietmar; Weber, Richard (2010). "The effects of entrepreneurship education", Journal of Economic Behavior and Organization, vol. 76, n 1, p. 90-112.

Griffin, Dale; Tversky, Amos (1992). "The weighting of evidence and the determination of confidence", Cognitive Psychology, vol. 24, n 3, p. 411-35.

Grimes, Paul W. (2002). "The overconfident principles of economics students: An examination of a metacognitive skill”, Journal of Economics Education, vol. 33, n 1, p. 15-30.

Grimes, Paul W.; Millea, Meghan J.; Woodruff, Thomas W. (2004). "Grades-Who's to blame? Student evaluation of teaching and locus of control", Journal of Economics Education, vol. 35, $\mathrm{n}^{\circ}$ 2, p. 129-147.

Haynes, Tara L.; Ruthig, Joelle C.; Perry, Raymond P.; Stupnisky, Robert H.; Hall, Nathan C. (2006). "Reducing the academic risks of over-optimism", Research in Higher Education, vol. 47, $\mathrm{n}^{\circ}$ 7, p. 755-779.

HAYWARD, Matthew L.A.; SHEPHERD, Dean A.; GRIFFIN, Dale (2006). "A hubris theory of entrepreneurship", Management Science, vol. 52, $\mathrm{n}^{\circ}$ 2, p. 160-172

Hayward, Matthew L.A.; Hambrick, D.C. (1997). "Explaining the premium paid for large acquisitions: Evidence of CEO hubris", Administrative Science Quarterly, vol. 42, n 1, p. 103127.

HMieleski, Keith M.; Baron, Robert A. (2008). "When does entrepreneurial self-efficacy enhance versus reduce firm performance?", Strategic Entrepreneurship Journal, vol. 2, n 1 , p. $57-72$.

Hmieleski, Keith M.; Baron, Robert A. (2009). “Entrepreneurs' optimism and new venture performance: A social cognitive perspective", Academy of Management Journal, vol. 52, $\mathrm{n}^{\circ} 3$, p. $473-488$.

Hoffrage, U. (2004). Overconfidence, in R.F. Pohl (Ed.), Cognitive illusions: Fallacies and biases in thinking, judgment, and memory, Hove, UK: Psychology Press, p. 235-254.

Jones, Campbell; Spicer, André (2009). Unmasking the entrepreneur, Cheltenham, UK: Edward Elgar, 160 p. 
KnaUP, Amy E. (2005). "Survival and longevity in the business employment dynamics data", Monthly Labor Review, Available At http: //www.bls.gov/opub/mlr/2005/05/ressum. pdf, Accessed January 21, 2015

Koellinger, Philipp; Minniti, Maria; Schade, Christian (2007). "I think I can, I think I can: Overconfidence and entrepreneurial behavior", Journal of Economic Psychology, vol. $28, \mathrm{n}^{\circ}$, p. $502-527$

Koku, Paul S.; Qureshi, Anique A. (2004). "Overconfidence and the performance of business students on examinations", Journal of Education for Business, vol. 79, $\mathrm{n}^{\circ}$ 4, p. 217-224.

LAZEAR, Edward (2005). "Entrepreneurship", Journal of Labour Economics, vol. 23, $\mathrm{n}^{\circ}$ 4, p. 649-680.

LI, Cheng H.; Wu, Jing J. (2011). “The structural relationships between optimism and innovative behavior", Creativity Research Journal, vol. 23, n², p. 119-128.

Lichtenstein, Sarah; FischHoff, Baruch (1977). "Do those who know more also know more about how much they know", Organizational Behavior and Human Performance, vol. 20, $\mathrm{n}^{\circ} 2$, p. $159-83$.

Linan, Francisco; Chen, Yi W. (2009). "Development and crosscultural application of a specific instrument to measure entrepreneurial intentions", Entrepreneurship Theory and Practice, vol. 33, n 3, p. 593-617.

Lowe, Robert A.; Ziedonis, Arvids A. (2006). "Over-optimism and the performance of entrepreneurial firms", Management Science, vol. 52, n 2, p. 173-186.

Luthnas, Fred; Avey, James B.; Patera, Jaime L. (2008). "Experimental analysis of a web-based training intervention to develop positive psychological capital", Academy of Management Learning \& Education, vol. 7, n 2, p. 209-221.

Maguire, Sarah; Guyer, Claire (2004). "Preparing geography, earth and environmental science students for employment in the enterprise culture", Journal of Geography in Higher Education, vol. 28, n³, p. 369-379.

Mangan, Katherine S. (2004). "Entrepreneurs in every department", Chronicle of Higher Education, vol. 50, May, p. A10-A11.

Mathieu, Cynthia; St. Jean, Etienne (2013). "Entrepreneurial personality: The role of narcissism", Personality and Individual Differences, vol. $55, n^{\circ} 5$, p. 527-531.

Mayo, M., Kakarika, M., Pastor, J.C. \& Brutus, S. 2012. Leadership self-image: A longitudinal study of responses to peer feedback in MBA teams. Academy of Management Learning \& Educaiton, 11(4), 621-652.

McColl-Kennedy, Janet R.; Anderson, Ronald D. (2005). "Subordinate-manager gender combination and perceived leadership style influence on emotions, self-esteem and organizational commitment", Journal of Business Research, vol. $58, \mathrm{n}^{\circ} 2$, p. $115-125$.

Miller, Tyler M., Geraci, Lisa (2011). "Unskilled but aware: Reinterpreting overconfidence in low-performing students", Journal of Experimental Psychology, vol. 37, n 2, p. 502-506.

Moules, J. (2012). The Rebel Entrepreneur: Rewriting the Business Rule Boom, Philadelphia, PA: Kogan Page, 224 p.

Nowell, Clifford; Alston, Richard M. (2007). "I thought I got an A! Overconfidence across the economics curriculum", Journal of Economics Education, vol. 38, n 2, p. 131-142.
Ottsen, Geir G.; Gronhaug, Kjell (2005). “Positive illusions and new venture creation: Conceptual issues and an empirical illustration", Creativity and Innovation Management, vol. 14, $\mathrm{n}^{\circ} 4$, p. 405-412.

Parajes, Frank, Miller, David M. (1994). "Role of self-efficacy and self-concept beliefs in mathematical problem solving: A path analysis", Journal of Educational Psychology, vol. 86, n ${ }^{\circ} 2$, p. 193-203.

Palich, Leslie E.; Bagby, Ray D. (1995). "Using cognitive theory to explain entrepreneurial risk taking: Challenging conventional wisdom", Journal of Business Venturing, vol. 10, $\mathrm{n}^{\circ}$ 6, p. 425-438.

Pardue, Karen T.; Morgan, Patricia (2008). "Millenials considered: A new generation, new approaches, and implications for nursing education", Nursing Education Perspectives, vol. 29, $\mathrm{n}^{\circ}$ 2, p. 74-79.

Payne, Stephen L.; Holmes, Barbara (1998). "Communication challenges for management faculty involving younger "Generation X" students in their classes", Journal of Management Education, vol. 22, n³, p. 344-367.

Perlmutter, David D. (2011). "Bridging the generational tech gap”, Chronicle of Higher Education, vol. 57, n 42, p. 55-58.

Peterson, Christopher (2000). "The future of optimism", American Psychologist, vol. 55, $\mathrm{n}^{\circ}$ 1, p. 44-55.

Reynolds, Paul D.; Bygrave, William D.; Autio, Erik (2004). "Global Entrepreneurship Monitor 2003 Global Executive Report", Babson College. Available at http: //www. gemconsortium.org/docs/download/259, Accessed January $21,2015$.

Roberts, Catherine. (1997). "So you want to be an entrepreneur?", Rochester Business Journal, vol. 12, n 47, p. 16.

Russo, Edward J.; Schoemaker, Paul J.H. (1992). "Managing overconfidence", Sloan Management Review, vol. 33, $\mathrm{n}^{\circ} 2$, p. 7-17.

Saunders, Shaun A.; Nolan, John; Provost, Steve (2009). "Student attributions and performance: Problems with unfounded optimism?", Research in Higher Education Journal, vol. 5, p. 1-8.

Scheier, Michael F.; Carver, Charles S.; Bridges, Michael W. (2001). Optimism, pessimism, and psychological wellbeing, in Edward C. Chang (Ed.), Optimism \& pessimism: Implications for theory, research, and practice, Washington, DC: APA, p. 189-216.

Simon, Mark; Houghton, Susan M. (2003). “The relationship between overconfidence and the introduction of risky products: Evidence from a field study", Academy of Management Journal, vol. 46, $\mathrm{n}^{\circ}$ 2, p. 139-49.

Simon, Mark; Houghton, Susan M.; Aquino, Karl (2000). "Cognitive biases, risk perception and venture formation: How individuals decide to start companies", Journal of Business Venturing, vol. 15, n 2, p. 113-134.

Seligman, Martin E.P.; Schilman, Peter (1986). "Explanatory style as a predictor of productivity and quitting amongst life insurance sales agents", Journal of Personality and Social Psychology, vol. 50, n 4, p. 832-838.

Shapero, Albert; SoKol, Lisa (1982). Social dimensions of entrepreneurship, in C. Kent et al. (Eds.), The encyclopedia of entrepreneurship, Englewood Cliffs, NJ: Prentice Hall, p. 72-90. 
Shelton, Lois M.; Danes, Sharon M.; Eisenman, Micki (2008). "Role demands, difficulty in managing work-family conflict, and minority entrepreneurs", Journal of Developmental Entrepreneurship, vol. 13, n 3, p. 315-342.

Sitzmann, Traci; Ely, Katherine; Brown, Kenneth G.; Baur, Kristina N. (2010). "Self-assessment of knowledge: A cognitive learning or affective measure?", Academy of Management Learning \& Education, vol. 9, n 2, p. 169-191.

Smith, Isaac H.; Woodworth, Warner P. (2012). "Developing social entrepreneurs and social innovators: a social identity and self-efficacy approach", Academy of Management Learning \& Education, vol. 11, n 3, p. 390-407.

Stajkovic, Alexander D.; Luthans, Fred (1998). "Selfefficacy and work-related performance: A meta-analysis", Psychological Bulletin, vol. 124, n 2, p. 240-61.

Svanum, Soren; Bigatti, Silvia (2006). "Grade expectations: Informed or uninformed optimism, or both?", Teaching of Psychology, vol. 33, n ${ }^{\circ}$ 1, p. 14-18.

Theng, Lau G.; Boon, Jasmine L.W. (1996). “An exploratory study of factors affecting the failure of local small and medium enterprises", Asia Pacific Journal of Management, vol. 13, n 2, p. 47-61.

Trevelyan, Rose (2011). "Self-efficacy and effort in new venture development", Journal of Management and Organization, vol. $17, \mathrm{n}^{\circ} 1$, p. 2-16

Trevelyan, Rose (2008). "Optimism, overconfidence and entrepreneurial activity", Management Decision, vol. 46, $\mathrm{n}^{\circ} 7$, p. 986-1001.

Trinugroho, Irwan; Sembel, Roy (2011). "Overconfidence and excessive trading behavior: An experimental study", International Journal of Business Management, vol. 6, $\mathrm{n}^{\circ} 7$, p. 147-152.

Twenge, Jean M. (2009). "Generational changes and their impact in the classroom: Teaching Generation Me", Medical Education, vol. $43, \mathrm{n}^{\circ}$ 5, p. 398-405.

Twenge, J. M., Konrath, S., Foster, J. D., Campbell, W. K., \& Bushman, B. J. 2008. Egos inflating over time: A crosstemporal meta-analysis of the Narcissistic Personality Inventory. Journal of Personality, 76: 875-901.

Veciana, José M.; Aponte, Marinés; Urbano, David (2005). "University students' attitudes towards entrepreneurship: A two country comparison", International Entrepreneurship and Management Journal, vol. 1, n 2, p. 165-182.

WAGNer, Joachim (2007). "What difference a Y makes - female and male nascent entrepreneurs in Germany", Small Business Economics, vol. 28, n 1, p. 1-21.

Weinstein, Neil D. (1980). "Unrealistic optimism about future life events", Journal of Personality and Social Psychology, vol. $39, \mathrm{n}^{\circ} 5$, p. $806-820$.

WooD, Gace (2006). "Recognizing the generational divide: When $\mathrm{X}$ meets $\mathrm{Y}$ at the tribal college", Tribal College Journal, vol. 17, $\mathrm{n}^{\circ} 4$, p. 24-25.

Wright, Dwan G.; Abell, Cathy H. (2011). "Using YouTube to bridge the gap between baby boomers and millennials", Journal of Nursing Education, vol. 50, n 5, p. 299-300.

Zhao, Hao; Seibert, Scott E.; Hills, Gerald E. (2005). “The mediating role of self-efficacy in the development of entrepreneurial intentions", Journal of Applied Psychology, vol. $90, \mathrm{n}^{\circ} 6$, p. 1265-1272. 